Nasibli F.A."

DOI: 10.25108/2304-1730-1749.iolr.2020.62.146-151

UDC: 005.574

\title{
Advantages of mediation over the court-based litigation process
}

Abstract: Mediation is a new concept in Azerbaijani legislation. So that the Law of the Republic of Azerbaijan on Mediation has been adopted on March 29, 2019, and the clauses regarding compulsory mediation will be entered into force on July 1, 2020. In this context, researches on mediation are attracting a great deal of attention nowadays.

In addition to negotiation, conciliation and arbitration, the other private form of alternative dispute resolution mechanisms is mediation. The disputing parties may choose all the abovementioned methods as an alternative to traditional courts. It is based on the agreement of the parties.

Mediation is a structured dispute resolution process in which the neutral and impartial third party brings together the disputing parties to negotiate and facilitates communication between them, although the decision-making power remains with the parties. The main purpose of mediation is not to reduce the intensity of the courts, but to eliminate the lack of communication between the parties with the help of professionals who have received mediation training.

The question in the present research is that why we need mediation? Or what is the best way for dealing with disagreements: mediation or litigation? Undoubtedly, the development of mediation is based on the goal of achieving justice, specifically the goal of ensuring social peace, which is desired as a result of resolving disputes or conflicts.

In order to find answers to these questions, it will be necessary to consider the advantages of mediation over the litigation and therefore sufficiently analyze the matter.

Keywords: mediation; litigation; court; dispute; interest; amicable agreement.

The world we live is full of discrepancies, disagreements and conflicts. Disputes and conflicts are based on the concept of struggle which can be defined as a basic function of living [4, p. 3 ]. The increased tendency to apply mediation shows that the parties may more often reach a peaceful solution through it rather than a court decision. So that it restores mutual relations of the parties and ensures the future transactions. Differently from mediation, court proceedings almost make the further cooperation of the opponents impossible. One may come to the conclusion that there is a need for mediation, first of all, to reach amicable and constructive solution. As stated in the Preamble to the United Nations Convention on International Settlement Agreements Resulting from Mediation, the use of mediation results in significant benefits, such as reducing the instances where a dispute leads to the termination of a commercial relationship [8, p. 3].

Peaceful solution may be reached through mediation for many reasons. One reason is that the "win-lose condition" does not exist in case of mediation. From the psychological point of view, win-lose condition" tends to produce a feeling of opposition and may lead to subsequent counterclaims [3, p. 181]. Conversely, as one of the main features of mediation is the resolution of conflict

\footnotetext{
- Nasibli Firuza Araz - Master student of the Commercial Law LL.M. Program at the Law Faculty of Baku State University, Azerbaijan. E-mail: firuze.nesibli.1997@gmail.com
} 
based on interest, legal assessments are not involved in mediation and do not constitute a basis for the resolution of the dispute. However the latter does not mean that the solution reached by the parties may be in contradiction with the existing legislation. According to Article 33.3 of the Law of the Republic of Azerbaijan on Mediation, the amicable agreement shall not contradict the legislation in force and the provisions of the first sentence of Article 3.3 of this Law [5].

As mediators try to understand and reconcile interests of the parties, mediation is sometimes referred to as an interest-based procedure, while litigation is referred to as a right-based procedure. With the effect of confidentiality and impartiality principles, it is possible for the parties to focus on their interests and needs, to better express themselves and their feelings. Conversely, litigation proceedings are generally held in open sessions. As the main element of successful mediation is confidentiality, mediation proceedings are closed, admission is limited, and it ensures the facts disclosed to be kept confidential. As is illustrated in Article 8.1 of the Law of the Republic of Azerbaijan on Mediation, mediation is held in closed sessions unless otherwise agreed between the parties [5].

Confidentiality is more important in mediation than in court. There is usually a provision in the chosen rules that no disclosure made during the mediation can be used at the next level of the dispute, whether arbitration or litigation. As though Article 10 of the Civil Procedure Code of the Republic of Azerbaijan lists instances which are treated as exceptions to the open court principle, these are limited with the cases that affect purposes of justice due to ethics principles of a democratic society, public order, state security, and regarding disclosure of state, professional or commercial secret, dissemination of personal and family secrets, pursuing interests of minors as well [1].

An impartial mediator will never resolve conflict by supporting the rights of the parties or deciding who is right and who is wrong. The only target is "happy ending" and searching for the solution that both the parties may accept. However, in litigation the parties insist on their positions and try to provide evidence for what they claim. Moreover, in judicial methods, it is not possible for the general and abstract laws that apply to everyone to predict every possibility and provide solutions for every concrete event. But in mediation the parties can develop a solution only for themselves, regardless of the existing regulations and procedures, and they do not have to stay in patterns created for everyone. As a result, it leads to creativity in seeking settlement and makes participants be less worried about problem. Therefore, as already mentioned one of the main components of mediation in civil disputes is conflict management. In order to support the healthy resolution of the parties' conflict situations, it is important to have information about the diagnosis of the conflict situation, the anatomy of the conflict and the factors that increase or decrease the conflict [7, p. 33]. Conflict refers to a situation change that, by nature, leads to new and effective solutions. In other words, in situations of conflict, the parties can develop and implement alternative solutions that they have never thought of before and that benefit both parties. Therefore, a successful mediator needs to manage the possible conflict well and support the emergence of solutions that can be effective for both parties.

In the court-based litigation procedure, the attention is paid to the positions, not interests. Although the Civil Procedure Code of the Republic of Azerbaijan demonstrates in Article 14.3 that the court shall be under an obligation to suggest parties to end dispute through amicable agreement, or in Article 52.3 that the parties shall have the right to close a case through an amicable agreement, [1] the unwillingness of the claimant and defendant to produce a wise agreement and the impossibility of changing their own positions are inevitable during litigation. 
In court the goal of the parties is victory because of the positional bargaining [6, p. 13]. It does not allow both sides to win at the same time unless there is a partial satisfaction of claim. Sometimes court decisions may be non-beneficial for both the parties simultaneously in the same case. It can be seen from the scope of application of mediation that, in fact the disputing sides are in long-term relationship; such as family members, business partners, employer and employee, or any part to civil dispute including neighbours, lessee and lesser, heirs and others. Therefore in most cases the ongoing relationship is much more important than the outcome reached [6, p. 20]. As stipulated in the appropriate Directive of the European Parliament and of the Council, agreements resulting from mediation are more likely to be complied with voluntarily and are more likely to preserve an amicable and sustainable relationship between the parties [2]. Additionally this outcome should be beneficial for both parties in order to maintain existing cooperation and ensure the further one.

The other advantage of mediation can be defined as the parties are not obliged to agree on a solution they are not satisfied with. Mediator does not have any authority to decide on the dispute. The parties are only and only decision-makers. The focus in mediation is to bring the parties together and facilitate them to come to a settlement. However, court by the means of decision determines exactly what the actual conclusion will be. The main purpose in the mediation is not to focus on the past but create a new future where both parties can be happy rather than the satisfaction of the injured due to conflict. In this regard one may come to this conclusion that the mediator does not make decisions for the parties and no one can force them to reach a decision. But in case of court hearing, both parties must comply with the court decision which is decided in the name of the state, otherwise non-compliance may result in civil, administrative or even criminal liability. The courts have at their disposal a limited arsenal of judicial remedies and decisions on the disputes they are considering, while mediation provides the freedom to search for a result that is in the interests of all parties to the dispute. So in mediation parties control over the outcome and such outcome may be reached or not, depending on the agreement of them. But in litigation an outcome definitely is reached. So if the dispute can't be resolved in mediation, the parties retain the rights to a hearing with a judge.

Mediation is designed to be faster and less expensive compared to the court. If there is any discrepancy, the right choice is to resolve dispute as soon as possible. Time extension may cause the dispute to grow and spread. Court trial is time-consuming. In any case, the time spent resolving the dispute through mediation is extremely short compared to the litigation. This saves time in conflict resolution. A time-saving method automatically results in cost savings. In this regard, mediation is an economically effective method, as it aims to resolve conflict in a week(s), days and even hours. In addition, costs for mediation is extremely low compared to costs for litigation (trial costs).

Where proceedings take place in non-courtrooms, opponents feel relaxed and comfortable. In practice, individuals feel anxious when they are compelled to go to court: they consider it as a decline of reputation, because when people hear of a court, it reminds them crimes or being sanctioned for any offence. The other reason is that litigation is formal differently from mediation.

With the presence of informality mediation also gives the parties such an opportunity to decide on procedural aspects of it, such as the choice of a mediator. Initially they plan the proceeding of the solution of their disputes. In this regard, it is distinguished from a national court on the grounds that in most cases (including the existing practice in Azerbaijan) national courts are not formed of judges who are expertises in particular field: generally they have common, but not special knowledge on the matters in question, or even sometimes it is difficult to submit a dispute to a con- 
cerning judge who is more qualified, because the latter deals with accidental cases, that is to say the parties cannot decide on a particular judge. Moreover, the litigation rules are considered in all cases and there is no exception. Nonetheless, there are various different types of mediation rules, and mediation does often proceed on case-by-case basis.

In fact, mediation is not a daily event in our state nowadays. However, one court exposes to deal with almost hundred cases each day, and it has an adverse effect in that sense the judge cannot focus on the detailed investigation of court cases both physically and on time. This means usually that a high influx of cases may result in underperformance of individual judges. Therefore, it is frequently stated that mediation and other forms of alternative dispute resolution mechanisms will reduce the caseload of traditional courts.

Consequently, this research has tried to answer the question of why mediation is useful in modern society. Apart from the fact that a court continues to exist as long as certain cases such as crimes, but excluding that of family matters, business cases, recruitment and employment issues, cannot be resolved through mediation, there is a strong need for mediation, at least within the instances which are overlapping with the litigation, in order to maintain long-life relationships and assure social peace between individuals. Therefore, it is useful to consider the advantages of mediation in comparison with the courts and to apply for mediation whether voluntarily or compulsorily as stipulated in the relevant legislation.

\section{References}

1. Azerbaycan Respublikasinin Mulki-Prosessual Mecellesi [Civil Procedure Code of the Republic of Azerbaijan]. Available at: http://www.e-qanun.az/code/9 (accessed 29.02.2020)

2. Directive 2008/52/EC of the European Parliament and of the Council of 21 May 2008 on certain aspects of mediation in civil and commercial matters. Available at: https://eurlex.europa.eu/legal-content/EN/ALL/?uri=CELEX\%3A32008L0052 (accessed 09.03.2020)

3. Gaffal, Margit. Psychosocial and Legal Perspectives of Marital Breakdown: With Special Emphasis on Spain. Springer, Berlin, Heidelberg, 2010. 257 p.

4. Keltner, John W. Sam. Mediation: Toward a Civilized System of Dispute Resolution. Illinois, $1987,74 \mathrm{p}$.

5. Mediasiya haqqinda” Azerbaycan Respublikasinin 2019-cu il 29 mart tarixli 1555-VQ nomreli Qanunu [The Law of the Republic of Azerbaijan on Mediation No. 1555-VQdated March 29, 2019]. Available at: http://www.e-qanun.az/framework/41828 (accessed 22.02.2020)

6. Roger Fisher and William Ury. Getting to yes. UK, 1999. 207 p.

7. Temel Arabuluculuk Egitimi Katilimci Kitabi [Basic Mediation Training Participant Book]. Book editors: Doç. Dr. Ali Yeşilirmak, Dr. Elif Kısmet Kekeç. Altan Özyurt Matbaacılık, Ankara, Turkey, 2017. 244 p.

8. "The United Nations Convention on International Settlement Agreements Resulting from Mediation. New York, 2019, 11 p. Available at: https:/uncitral.un.org/ sites/uncitral.un.org/ files/media-documents/EN/Texts/UNCITRAL/Arbitration/mediation_convention_v1900316 _eng.pdf (accessed 08.03.2020) 
Насибли Ф.А.

DOI: $10.25108 / 2304-1730-1749.10 l r .2020 .62 .146-151$

УДК: 005.574

\section{Преимущества медиации над судебным процессом}

Аннотация: Медиация (или посредничество) является новой концепцией в законодательстве Азербайджана. Так, Закон Азербайджанской Республики “О медиации” был принят 29 марта 2019 года, а положения, касающиеся обязательного медиации, вступят в силу 1 июля 2020 года. В этом контексте исследования медиации привлекают большое внимание в настоящее время.

Помимо переговоров, примирения и арбитража, другой частной формой альтернативных механизмов разрешения споров является медиация. Стороны в споре могут выбрать все вышеупомянутые методы в качестве альтернативы традиционным судам. Это основано на соглашении сторон.

Посредничество - это структурированный процесс разрешения споров, в котором нейтральная и беспристрастная третья сторона объединяет спорящие стороны для ведения переговоров и облегчает общение между ними, хотя полномочия по принятию решений остаются за сторонами.Основная цель медиации заключается не в том, чтобы снизить интенсивность работы судов, а в том, чтобы устранить недостаток общения между сторонами с помощью специалистов, прошедших обучение медиации.

Вопрос в настоящем исследовании заключается в том, почему нам нужно посредничество? Или как лучше всего справляться с разногласиями: посредничество или судебный процесс? Несомненно, развитие посредничества основано на цели достижения справедливости, а именно цели обеспечения социального мира, который желателен в результате разрешения споров или конфликтов.

Чтобы найти ответы на эти вопросы, необходимо рассмотреть преимущества посредничества над судебным процессом и, следовательно, достаточно проанализировать вопрос.

Ключевые слова: посредничество; медиация; судебный процесс; суд; спор; интерес; мировое соглашение.

\section{Библиография}

1. Гражданский Процессуальный Кодекс Азербайджанской Республики. [Электронный pecypc] - Режим доступа: http://www.e-qanun.az/code/9 (дата обращения: 29.02.2020) (на азерб. яз.).

2. Директива 2008/52/ЕС Европейского Парламента и Совета от 21 Мая 2008 г относительно некоторых аспектов медиации в гражданских и коммерческих делах. [Электронный

\footnotetext{
- Насибли Фируза Араз кызы - магистр Коммерческого права юридического факультета Бакинского Государственного Университета, Азербайджан. E-mail: firuze.nesibli.1997@gmail.com
} 
pecypc]. - Режим доступа: https://eur-lex.europa.eu/legal-content/EN/ALL/?uri=CELEX\% 3A32008L0052 (дата обращения: 09.03.2020).

3. Гаффал Маргит. Психосоциальные и правовые перспективы распада брака: с особым акцентом на Испанию. - Берлин, Спрингер, Гейдельберг, 2010. - 257 с.

4. Келтнер, Джон У. Сэм. Посредничество: на пути к цивилизованной системе разрешения споров. - Иллинойс, 1987. - 74 с.

5. Закон Азербайджанской Республики “О медиации””№ 1555-VQ от 29 марта 2019 года. [Электронный ресурс] - Режим доступа: http://www.e-qanun.az/framework/41828 (дата обращения: 22.02.2020) (на азерб. яз.).

6. Роджер Фишер и Уильям Ури. Переговоры без поражения. Великобритания, 1999. $207 \mathrm{c}$.

7. Базовая книга участников медиации. Редакторы книг: доц. Д-р Али Есилирмак, доктор Элиф Кисмет Кекеч. - Анкара, Алтан Озюрт Полиграфия, 2017. - 244 с. (на турец. яз.)

8. Конвенция Организащии Объединенных Наций о международных мировых соглашениях, достигнутых в результате медиации. Нью-Йорк, 2019, 11 с. [Электронный ресурс] - Режим доступа: https://uncitral.un. org/sites/uncitral.un.org/files/mediadocuments/EN/Texts/ UNCITRAL/Arbitration/ mediation_ convention_v1900316_eng.pdf (дата обращения: 08.03.2020). 